\title{
EFFECT OF DIPHTHERIA TOXIN T-DOMAIN ON ENDOSOMAL pH
}

\author{
A. J. LABYNTSEV, N. V. KOROTKEVYCH, D. V. KOLYBO, S. V. KOMISARENKO
}

\author{
Palladin Institute of Biochemistry, National Academy of Sciences of Ukraine, Kyiv; \\ e-mail: lab.andrey@gmail.com
}

A key step in the mode of cytotoxic action of diphtheria toxin (DT) is the transfer of its catalytic domain (Cd) from endosomes into the cytosol. The main activity in this process is performed by the transport domain (Td), but the molecular mechanism of its action remains unknown. We have previously shown that Td can have some influence on the endosomal transport of DT. The aim of this work was to study the effect of diphtheria toxin on the toxin compartmentalization in the intracellular transporting pathway and endosomal $\mathrm{pH}$. We used recombinant fragments of DT, which differed only by the presence of Td in their structure, fused with fluorescent proteins. It was shown that the toxin fragment with Td moved slower by the pathway early-late endosomes-lysosomes, and had a slightly different pattern of colocalization with endosomal markers than DT fragment without Td. In addition, endosomes containing DT fragments with Td had a constant $\mathrm{pH}$ of about 6.5 from the $10^{\text {th }}$ to $50^{\text {th }}$ minute of observation, for the same time endosomes containing DT fragments without Td demonstrated a decrease in $\mathrm{pH}$ from 6.3 to 5.5. These results indicate that Td inhibits acidification of endosomal medium. One of possible explanations for this may be the effect of the ion channel formed by the $T$-domain on the process of the endosomal acidification. This property of Td may not only inhibit maturation of endosomes but also inhibit activation of endosomal $\mathrm{pH}$-dependent proteases, and this promotes successful transport of Cd into the cell cytosol.

Key words: diphtheria toxin, T-domain of diphtheria toxin, endocytosis, fluorescent proteins, confocal microscopy, endosomal $\mathrm{pH}$.

$\mathrm{D}$ iphtheria is a bacterial infection of the upper respiratory tract with possible complications in tissues and organs of the affected organism (the kidneys, heart, nervous system, etc.). The disease is caused by toxigenic strains of Corynebacterium diphtheriae, which can synthesize the main pathogenicity factor - diphtheria toxin (DT). This protein is a simple polypeptide of 535 amino acids long. It may be structurally divided into 3 domains: C-domain $(\mathrm{Cd})$ is a specific ADPribosyltransferase with eEF-2 (eukaryotic translation elongation factor 2); T-domain (Td) is responsible for $\mathrm{pH}$-dependent $\mathrm{Cd}$ transport through the lipid bilayers; R-domain has an ability to specific interaction with a cell receptor, a transmembrane form of heparin-binding EGF-like growth factor (proHBEGF). Toxin is assigned to $A B$ group of bacterial toxins, thus, it is divided into a subunit A responsible for the enzymatic activity, which corresponds to Cdomain, and a subunit B (SubB), includes Td and Rd and responsible for the transport of the subunit A.

The mechanism of DT activity may be presented as the following stages. Rd interacts with proHB-EGF receptor on the cell surface; such interaction stimulates the formation of endosome with a toxin-receptor complex in a clathrin-mediated way. A decrease of $\mathrm{pH}$ inside such endosome is followed by the change of Td conformation; it inserts into the endosomal lipid bilayer and transports $\mathrm{Cd}$ to cytoplasm. After the translocation $\mathrm{Cd}$ becomes activated and modifies eEF-2. ADP-ribosylated eEF-2 inhibits the ribosomal activity; that is why the accumulation of the large amount of this modified factor leads to the arrest of protein synthesis and further death of cells. A scheme of toxin functioning is revealed in more detail in the review [1].

The endosomal cell apparatus consists of several main compartments, where vesicles can arrive after the process of its formation. Such compartments may include early endosomes (EE) which can be headed to recycling endosomes (RE) or maturate to late endosomes (LE) and then to lysosomes [2]. The main marker of maturation and LE formation is the formation of multivesicular bodies (MVB) which are the endosomes included as the bodies in EE. Then such vesicles become directed to degra- 
dation through LE to lysosomes. The endosomal sorting complex required for transport (ESCRT) is responsible for MVB formation. This complex includes the large number of proteins responsible for sorting and direction of the sorted endosomes with cargo for further degradation in LE. There are several stages of the complex assembling: ESCRT-0, ESCRT-I and ESCRT-II binds to ubiquitinated fragments on the surface of endosomes and sorts them; besides, ESCRT-II starts the process of endosomal entry into MVB by membrane invagination, ESCRTIII (CHMP4, and then CHMP6 being incorporated in this complex) continues and completes this process. Thus the components of ESCRT-III complex may be detected both in EE (at the stage where sorting begins) and in LE after MVB formation. The next stage is dissociation of ESCRT-III complex with Vps4(SKD1)-Vta1 complex, and further LE association with lysosomes with the help of Rab5-NSFSNAP complex [3]. It is important to note that the inhibition of ESCRT-III dissociation hinders the further LE fusion with lysosomes [4]. The process of $\mathrm{LE}$ maturation includes a decrease of endosomal $\mathrm{pH}$ as a result of the effect of proton pumps of vesicular type (V-ATPase), $\mathrm{pH}$ in EE may be 6.8-6.1, $\mathrm{pH}$ in $\mathrm{LE}-6.0-4.9, \mathrm{pH}$ in lysosomes may be below 4.8. It is known that EE transport to LE may be blocked by the $\mathrm{pH}$ stabilizers (like $\mathrm{NH}_{4} \mathrm{Cl}$ ) or inhibitors of V-ATPase [2]. Endosomal proteases - catepsins are also transported to LE, most of them are activated at $\mathrm{pH}$ below 6 and can function in both LE and lysosomes [5].

The diphtheria toxin is the one of the first toxins of bacterial origin which was actively studied by the world scientific community. That is evidenced by the large number of publications which deal with the structure, role of each domain, features of synthesis and realization of its toxic function. Nevertheless, many aspects of Td functioning remain to be cleared up. In the previous work we have revealed the $\mathrm{Td}$ effect on the transport of DT fragments [6]. So, the aim of this work was to investigate the peculiarities of such effect studying the pathways of intracellular transportation of DT fragments and Td effect on the endosomal $\mathrm{pH}$.

\section{Materials and Methods}

Obtaining of genetic constructs encoding pHluorin, $\mathrm{pH}$-SubB and $\mathrm{pH}-\mathrm{Rd}$ proteins. The plasmid pKK223-3/pHluorin (M153R) was used as the donor nucleotide sequence for a gene of $\mathrm{pH}$-sensitive protein pHluorin(M153R) [7, 8].
The gene pHluorin(M153R) was amplified by PCR with a sense primer GAA CT and antisense primers ATA CTC GAG TTT GTA TAG TTC ATC CAT GC (for the construction which expressed pHluorin(M153R)) and ATA GAC GTC TTT GTA TAG TTC ATC CAT GC (for the construction which expressed proteins $\mathrm{pH}-\mathrm{SubB}$ and $\mathrm{pH}-\mathrm{Rd}$ ). The diphtheria toxin gene fragments which coded SubB (Rd and Td) and Rd alone were amplified from cell lysates of $C$. diphtheriae strain NCTC 10648 (Central Kyiv Sanitary Epidemic Station) with the described primers [9]. The expression construct pET28a-pHluorin was created by combining nucleotide sequences of plasmid vector pET28a (Novagen, USA) and a gene fragment which encoded pHluorin(M153R) by the restriction sites BamHI and Xhol. DT gene fragments SubB and Rd were fused with pHluorin(M153R) gene into a single reading frame by the restriction site AatII. The chimeric genes $\mathrm{pH}-\mathrm{SubB}$ and $\mathrm{pH}-\mathrm{Rd}$ were also insereted into the vector pET28a by the sites BamHI and XhoI, with creation of the expression constructs pET28apH-SubB and pET28a-pH-Rd, respectively.

The obtained constructs pET28a-pHluorin, pET28a-pH-SubB and pET28a-pH-Rd were introduced in the expression strain Escherichia coli BL 21 (DE3) Rosetta (Novagen, USA) by electroporation. The correctness of the performed operations was verified by the restriction analysis and according to functional activity of target proteins.

Expression of recombinant proteins. The recombinant proteins used in this study: pHluorin, mCherry, pH-SubB, mCh-SubB, pH-Rd and mChRd were obtained from the culture $E$. coli strain BL 21 (DE3) Rosetta transformed by the corresponding genetic structures.

The bacterial culture was grown at $37{ }^{\circ} \mathrm{C}$ in conditions of intensive aeration (250 RPM) up to the optical density A600 - 0.5-0.7 in the medium $2 \mathrm{xYT}$, which contained $50 \mathrm{mg} / 1$ of kanamycin and $170 \mathrm{mg} / \mathrm{l}$ of chloramphenicol. The protein expression was induced by adding isopropyl- $\beta$-Dthiogalactopyranoside (IPTG) to concentration of $1 \mathrm{mM}$ and was performed during $3 \mathrm{~h}$ at $30^{\circ} \mathrm{C}$ under intensive aeration (250 RPM), then the cells were centrifuged at $3300 \mathrm{~g}$ for $10 \mathrm{~min}$.

Purification of recombinant proteins with immobilized metal ion affinity chromatography (IMAC). Recombinant protein was isolated by IMAC on a column with affine sorbent $-\mathrm{Ni}^{2+}$-NTA-agarose. The column with affine sorbent was equilibrated by 
buffer E (50 mM Na $\mathrm{HPO}_{4}, 0.5 \mathrm{M} \mathrm{NaCl}, 10 \mathrm{mM}$ imidazole, $\mathrm{pH}$ 8.0) with $8 \mathrm{M}$ urea. The precipitated bacterial cells were resuspended in the buffer $\mathrm{E}$ with $8 \mathrm{M}$ urea in ratio 1:10 (ml per $\mathrm{ml})$. Then the samples were treated by ultrasound homogenizer LabsonicM (Sartorius, Germany). Cell debris were removed by 10000 g centrifugation for $15 \mathrm{~min}$, while supernatant was renaturated by gradual drop-wise dilution in buffer $E$ in ratio 1:10 with continuous stirring. After renaturation the solution was clarified at $10000 \mathrm{~g}$ for $15 \mathrm{~min}$, and the supernatant was loaded into the column with $\mathrm{Ni}^{2+}$-NTA-agarose.

The column was rinsed by 6 volumes of the buffer solution $\mathrm{E}$. The protein was eluted by the buffer $\mathrm{E}$ with $400 \mathrm{mM}$ of imidazole. For further use the protein was dialyzed against PBS $(0.14 \mathrm{M} \mathrm{NaCl}$, $0.03 \mathrm{M} \mathrm{KCl}, 0.011 \mathrm{M} \mathrm{Na}_{2} \mathrm{HPO}_{4}, 0.002 \mathrm{M} \mathrm{KH}_{2} \mathrm{PO}_{4}$, $\mathrm{pH}$ 7.2).

Electrophoretic separation of proteins. Electrophoresis in polyacrylamide gel with sodium dodecyl sulfate was performed following the modified method by H. Schagger [10].

Cultivation of Vero cells. The Vero cell line, originating from the kidney epithelium of green monkey (Cercopithecus aethiops), was received from the bank of cell line of R. E. Kavetsky Institute of Experimental Pathology, Oncology and Radiobiology (Kyiv, Ukraine). The Vero cell line was cultivated on RPMI-1640 with L-glutamine which contained $5 \%$ of fetal calf serum, streptomycin (100 mg/l), penicillin (10 $000 \mathrm{U}$ ) and amphotericin B $(250 \mu \mathrm{g} / \mathrm{l})$ with $5 \%$ of $\mathrm{CO}_{2}$ in the atmosphere.

Investigation of spectral properties of proteins pHluorin, $\mathbf{p H}-\mathrm{SubB}$ and $\mathbf{p H}-\mathrm{Rd}$ was conducted by spectrofluorimeter QuantaMaster 400 (Photon Technology International, Canada). MES (2-(Nmorpholino)ethanesulfonic acid)-gluconate buffer (140 mM NaCl, 20 mM MES, 5 mM Na gluconate) was used to determine $\mathrm{pH}$-dependent fluorescence of these proteins in the range of $\mathrm{pH}$ 4.5-7.5.

Flow cytometry. Cells were detached from flask surface by $20 \mathrm{mM}$ EDTA in PBS. Optimal quantity of cell for staining was $0.3-0.5 \cdot 10^{6}$ per one sample. The cells used for staining with fluorescent proteins were previously precipitated at 200-300 g for $10 \mathrm{~min}$, and protein in required concentration was added in $200 \mu \mathrm{BSA}$ (bovine serum albumin)/ PBS (0.14 M NaCl, $0.03 \mathrm{M} \mathrm{KCl,} 0.011 \mathrm{M} \mathrm{Na}_{2} \mathrm{HPO}_{4}$, $0.002 \mathrm{M} \mathrm{KH}_{2} \mathrm{PO}_{4}, 1 \% \mathrm{BSA}, \mathrm{pH}$ 7.2) solution.

Cells were stained for $20 \mathrm{~min}$ at $4{ }^{\circ} \mathrm{C}$. To remove unbound proteins, we added solution BSA/
PBS to $1 \mathrm{ml}$, accurately resuspend cells, spinned down them at 200-300 $\mathrm{g}$ for $10 \mathrm{~min}$ and substituted the incubation medium solution by $1 \mathrm{ml}$ BSA/PBS. Then the solution of stained cells was transferred to test-tubes for cytometer.

Cell fluorescence intensity was determined on flow cytometer Coulter Epics XL (Beckman Coulter, USA). The parameters used in the research record: forward scattering (FS), side scattering (SS) and the logarithm of fluorescence on FL1 channel (515$535 \mathrm{~nm}$ ) for samples with pHluorin and FL3 channel (610-630 nm) for samples with mCherry. Two plots were calculated using these parameters: dot plot of cell morphology (forward vs side scattering) and histogram of fluorescence intensity on FL1 or F13 channel. The number of events for calculated plots was 10000 .

Confocal microscopy of fixed cells. The Vero cells were preliminarily seeded on the cover glass and then transfected with plasmids pGFPSKD1 ${ }_{\text {E235Q, }}$ pCHMP4b-GFP or pCHMP6-GFP using a transfection reagent Lipofectamine LTX (LifeTechnologies, USA).

The cells were stained with fluorescent proteins (145 nM mCh-Rd and $390 \mathrm{nM} \mathrm{mCh-SubB)}$ and $10 \mu \mathrm{M}$ nuclear stain Hoechst 33342 in RPMI-1640 (pH 7.3) and then incubated at $37^{\circ} \mathrm{C}$ for 15 to $60 \mathrm{~min}$. Solution with unbound proteins were removed after 15 min of incubation, and only solution of RPMI1640 with $10 \mu \mathrm{M}$ Hoechst 33342 was used for the subsequent incubation. The cells were fixed by 4\% paraformaldehyde in $0.1 \mathrm{M}$ phosphate buffer (pH 7.4) for $40 \mathrm{~min}$ at $4{ }^{\circ} \mathrm{C}$. The cover glass with cells was mounted to microscopic slide with the cell mounting medium based on polyvinyl alcohol and 1,4-diazabicyclo[2.2.2]octane.

Slides were analyzed on confocal microscope Carl Zeiss LSM 510 Meta (Carl Zeiss, Germany) with oil immersion lens Plan-Apochromat $63 \mathrm{x} / 1.4$ Oil DIC. $488 \mathrm{~nm}$ laser was used to excite chromophore EGFP and $543 \mathrm{~nm}$ to excite chromophore mCherry, information about fluorescence was taken from 505-530 nm channel for EGFP and 560-615 nm for mCherry. The stain Hoechst 33342, used for contrasting the nuclei, was excited by $405 \mathrm{~nm}$ laser and detected on the 420-480 nm channel .

Live cell imaging. The Vero cells were preliminarily grown to semiconfluent state on a cover glass or special Petri dish with $0.17 \mu \mathrm{m}$ thin glass bottom.

Prior to investigation the chamber for lifetime examination installed on the confocal micro- 
scope Carl Zeiss LSM 510 Meta was heated for $2 \mathrm{~h}$ to the constant temperature of $37^{\circ} \mathrm{C}$. Live cells which grew in a special Petri dish or a metal chamber with a cover glass were preliminarily washed up by the HBSS (Hank's Buffered Salt Solution): $0.137 \mathrm{M} \mathrm{NaCl}, 5.4 \mathrm{mM} \mathrm{KCl}, 0.25 \mathrm{mM} \mathrm{Na}_{2} \mathrm{HPO}_{4}$, 0.1 g glucose, $0.44 \mathrm{mM} \mathrm{KH}_{2} \mathrm{PO}_{4}, 1.3 \mathrm{mM} \mathrm{CaCl}_{2}$, $1.0 \mathrm{mM} \mathrm{MgSO}_{4}, 4.2 \mathrm{mM} \mathrm{NaHCO}_{3}$, $\mathrm{pH}$ 7.3. The main working solution was the HBSS with $1 \%$ BSA and $25 \mathrm{mM}$ HEPES. The cells were stained with protein pHluorin, $\mathrm{pH}-\mathrm{SubB}$ or $\mathrm{pH}-\mathrm{Rd}$. After 5-7 min of incubation, the cells were washed up and aliquot of HBSS was added. Live cell experiments were carried out during $50 \mathrm{~min}$.

Fluorescence of $\mathrm{pH}$-sensitive fluorescent protein pHluorin and DT derivatives $\mathrm{pH}$-SubB and $\mathrm{pH}$-Rd was detected through the oil immersion lens Plan-Apochromat 63x/1.4 Oil DIC on 505-550 nm channel after excitation by lasers of $405 \mathrm{~nm}$ and $488 \mathrm{~nm}$. Shooting frequency was 1-5 min/frame, shooting rate was 1-2 frame/s.

Analysis of confocal microscopy data. The obtained data of collocalization of fluorescent DT derivatives with intracellular transport pathway markers were analyzed with FIJI software with JACoP plugin $[11,12]$. Calibration curves of $\mathrm{pH}$ vs fluorescence of proteins $\mathrm{pH}-\mathrm{SubB}$ and $\mathrm{pH}-\mathrm{Rd}$ were plotted based on confocal images of nanoparticles PLGA loaded with $\mathrm{pH}-\mathrm{SubB}$ and $\mathrm{pH}-\mathrm{Rd}$. The technique of synthesis of such nanoparticles (method PLGA2) was presented in our previous publication [13]. The analysis of $\mathrm{pH}$ variations inside endosomes with DT derivatives was performed by the script written in the Python 2.7 language [14] with libraries OpenCV [15], Matplotlib [16], NumPy [17], Pillow (PIL Fork) (Alex Clark and contributors, https://pillow.readthedocs.org/), openpyxl (Eric Gazoni, https://openpyxl.readthedocs.org/). The program code is available at https:/github.com/AndriiLab/ImageAnalysisScripts/blob/master/ratioBetweenTwoChannelsBetweenTwoProteins.py.

\section{Results and Discussion}

Study of the effect of diphtheria toxin T-domain on the intracellular toxin transport. We have previously shown that colocalization between proteins SubB (consists of $\mathrm{Rd}$ and $\mathrm{Td}$ ) and $\mathrm{Rd}$ alone increases up to the $60^{\text {th }}$ min of investigation, but from the $60^{\text {th }}$ min proteins probably follow different transporting paths because of a decrease of their colocalization from that time [6]. That is why it was important to study which intracellular transport compartments DT fragments pass through and whether these proteins have different paths of intracellular transport.

Several markers of endosomal transport were used to study the DT transporting pathway. Plasmids pCHMP4b-GFP [18] and pCHMP6-GFP [19] coded fluorescent derivatives of proteins-markers $\mathrm{EE}$ and LE - CHMP4b and CHMP6, respectively. Plasmid pGFP-SKD1 ${ }_{\mathrm{E} 235 \mathrm{Q}}$ [4] coded fluorescent mutant protein SKD1 ${ }_{\mathrm{E} 235 \mathrm{O}}$ which does not lead to LE fusion with lysosomes but to formation of E235Q-compartment, where proteins remain over a rather long period of time. E235Q-compartment is MVB which cannot already be directed on the recycling path, however it also cannot fuse with lysosomes since ESCRT-III complex is available at the surface.

The scheme of cloning and purification of proteins mCherry, $\mathrm{mCh}$-SubB and mCherry-Rd used in the work was described in more detail [9]. The Vero line cells which had been transfected by different markers of endosomal transport and then stained with DT fragments were used in the work. Manders coefficients were calculated by FIJI software from confocal images for proteins SubB and Rd and markers of endosomal pathway. These coefficients represented part of colocalized DT derivate with the marker of endosomal pathway, i.e. Manders coefficient equal to 1 corresponds to $100 \%$ colocalization between studied proteins. Such analysis is described in more detail in our previous work [6].

Results on Fig. 1 present graphs of time-dependent colocalization of SubB and Rd with the markers of the endosomal pathway. According to investigation data for SubB colocalization with a marker CHMP4b in the time interval of 15-30 min SubB was weakly colocalized with CHMP4b (2$6 \%$ ), but on the $45^{\text {th }}$ min of research $62 \%$ of SubB were colocalized with CHMP4b, on the $60^{\text {th }} \mathrm{min}$ of research only $27 \%$ of SubB were colocalized with the given marker. During 15-45 min of research Rd was colocalized with CHMP4b by $7-25 \%$, and on the $60^{\text {th }}$ min the colocalization of Rd was above $80 \%$. A similar pattern of SubB and Rd colocalization was demonstrated for protein CHMP6. On the $15^{\text {th }} \mathrm{min}$ of research colocalization of SubB with CHMP6 was $40 \%$, further colocalization between SubB and CHMP6 decreased to $15-20 \%$ (on the $30-45^{\text {th }}$ min) and $5 \%$ (on the $60^{\text {th }} \mathrm{min}$ ). Rd, on the contrary, was weakly colocalized with CHMP6 for $15-45^{\text {th }}$ min of research (about 1-5\%), and on the $60^{\text {th }}$ min of 
research its colocalization with CHMP4b was $30 \%$. Thus, the appearance of SubB in EE and LE, according to the data of colocalization with proteins CHMP4b and CHMP6, may be noted from the 15$30^{\text {th }}$ min and its partial outlet from this compartment on the $60^{\text {th }}$ min of incubation, but a considerable amount of Rd in these compartments may be noted from the $45-60^{\text {th }} \mathrm{min}$.

To reveal the time of SubB and Rd transfer to lysosomes we have determined their colocalization with protein SKD1, which is a marker of the last stages of LE formation. Colocalization between Rd and SKD1 increased from 15 to $30 \mathrm{~min}$ from $0 \%$ to $36 \%$, further we observed a decrease of colocalization to about $20 \%$ on the $45-60^{\text {th }}$ min of research. Colocalization between SubB and SKD1 was almost unchanged $(\approx 15 \%)$ during $15-45 \mathrm{~min}$, but on the $60^{\text {th }}$ min of research colocalization between SubB and SKD1 was about 85\% that indicated the fact that the overwhelming majority of SubB was directed to lysosomes. Thus, Rd from the $30^{\text {th }} \mathrm{min}$ is colocalized with a lysosomal marker, SubB is colocalized with this marker only from the $60^{\text {th }}$ min. Maybe, an increase of colocalization between SubB and Rd,
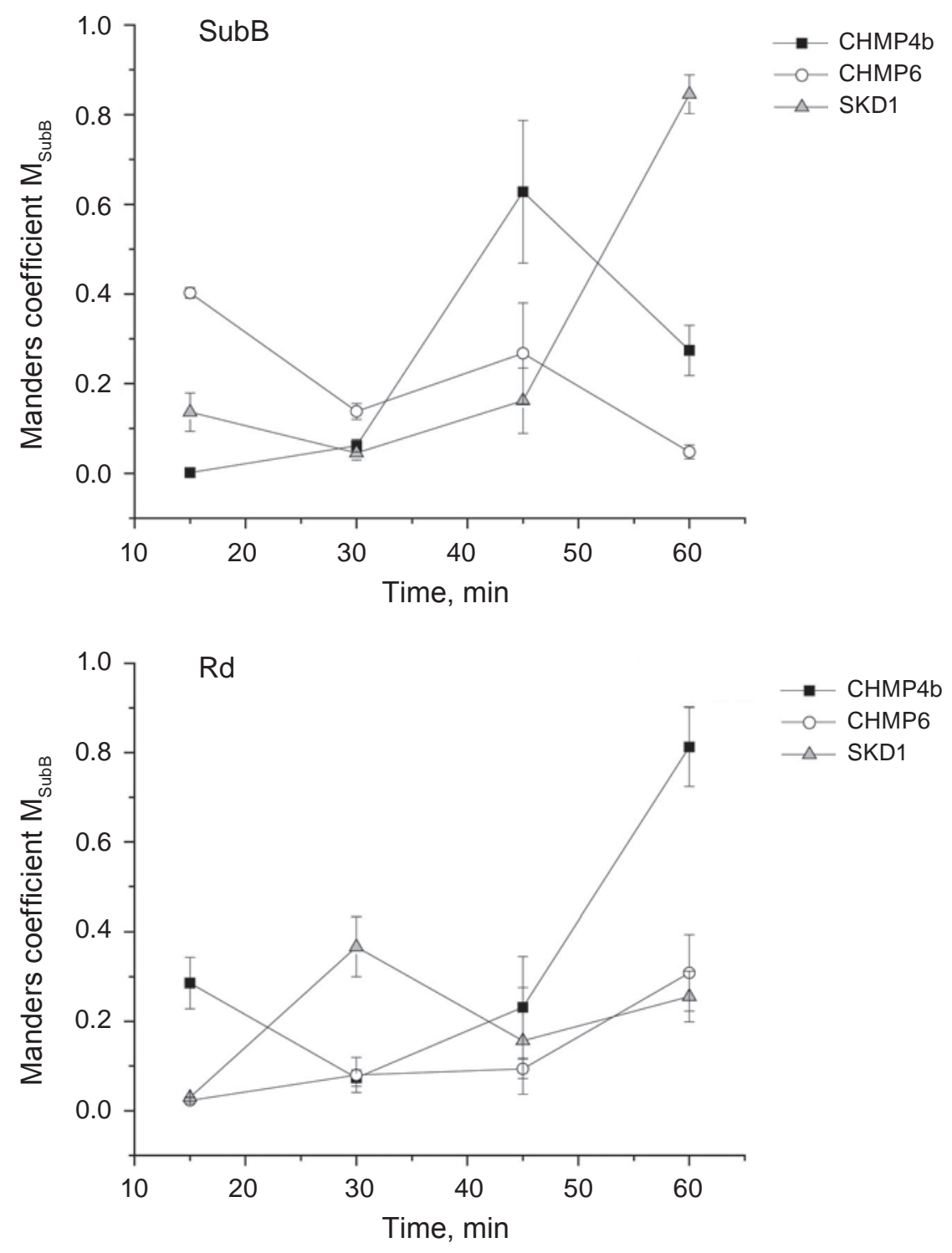

Fig. 1. Colocalization graphs of DT fragments (SubB and Rd) with different markers endosomal pathway vs incubation time. Graphs show changes in time of colocalization of SubB and Rd with markers endosomal pathway CHMP4b, CHMP6 and SKD1 from $15^{\text {th }}$ to $60^{\text {th }}$ min of observation calculated as changes in Manders coefficients $M_{\text {SubB }}$ and $M_{R d}(M \pm S E, n=3-6)$ 
shown in the previous work [6], is connected with SubB and Rd accumulation in EE or LE.

The analysis of time-dependent quantity change of SubB and Rd colocalized with endosomal markers has also revealed certain differences in transport of these proteins. On the $15^{\text {th }}$ and $45^{\text {th }}$ min of research SubB was mainly colocalized with CHMP6 and CHMP4b, respectively, and on the $60^{\text {th }}$ min SubB was mainly colocalized with SKD1. Thus, from the $15^{\text {th }}$ to the $45^{\text {th }}$ min SubB was probably in EE or LE, and from the $60^{\text {th }} \mathrm{min}$ it passed to lysosomal compartment. During the $30^{\text {th }}-60^{\text {th }}$ min of research about $20-35 \%$ of Rd were colocalized with lysosome marker, however, on the $60^{\text {th }} \mathrm{min}$ of research about $80 \%$ of $\mathrm{Rd}$ were colocalized with a marker of EE and LE. Notably that from the $30^{\text {th }} \mathrm{min}$ Rd begins arriving to lysosomal compartment, but a rather low percentage of colocalization with the lysosomal marker may indicate to rapid degradation of this protein in lysosomes. Another explanation of a low level of colocalization between these proteins may be associated with recycling of proHB-EGF-Rd complex which can go through the LE to EE and their exocytosis (these peculiarities of Rd transport require further investigations).

As a result of this experiment we have demonstrated differences in the velocity of intracellular transport of SubB and Rd, and probably, the differences in certain stages of their intracellular transport pathways. It is shown that SubB arrives later to LE and lysosomes. It is probable that SubB is able to affect the velocity of endosomal maturation via the potential property of T-domain to form proton channels in a membrane [20].

Obtaining of recombinant fluorescent proteins based on pH-sensitive protein and SubB or Rd. To study the effect of SubB on the velocity of endosomal maturation by determining $\mathrm{pH}$ inside the endosomes it was decided to use an improved variant of $\mathrm{pH}$-sensitive fluorescent protein pHluorin(M153R). M153R-mutation not only increased its stability but also increased the fluorescence brightness of this mutant protein [7]. We obtained chimeric proteins which consisted of this fluorescent protein and DT fragments SubB and Rd - pH-SubB and pH-Rd, respectively.

The scheme of obtaining genetic constructs, encoding proteins $\mathrm{pH}-\mathrm{SubB}$ and $\mathrm{pH}-\mathrm{Rd}$, included amplification by specific primers for SubB and $\mathrm{Rd}$ from lysates of $C$. diphtheriae of strain NCTC 10648 and amplification of nucleotide sequence of fluorescent protein pHluorin(M153R) from plasmid pKK223-3/pHluorin(M153R). Obtained nucleotide sequences of DT fragments and fluorescent protein were inserted into plasmid vector pET-28a $(+)$ with further obtaining of expression vectors pET28apHluorin, pET28a-pH-SubB and pET28a-pH-Rd. The obtained genetic constructs were used to transform E. coli bacteria of strain BL21 Rosetta (DE3) and for selection of colonies with high expression level of required proteins.

Recombinant proteins used in the work were purified by IMAC on $\mathrm{Ni}^{2+}$-NTI sorbent. As was known from previous works $[6,9]$ target proteins based on DT fragments were insoluble, the procedure of their renaturation was performed to obtain a soluble protein. Fig. 2 presents electrophoregram of proteins pHluorin, $\mathrm{pH}-\mathrm{SubB}$ and $\mathrm{pH}-\mathrm{Rd}$ obtained in the work after their renaturation and purification on the affine sorbent. Molecular weights of chimeric proteins corresponded to the expected molecular weights 35, 70 and $48 \mathrm{kDa}$ for pHluorin, $\mathrm{pH}-\mathrm{SubB}$ and $\mathrm{pH}-\mathrm{Rd}$, respectively.

Establishing functional activity of chimeric proteins based on pHluorin(M153R). For the further work with obtained proteins based on pHluorin(M153R) and DT fragments it was neces-

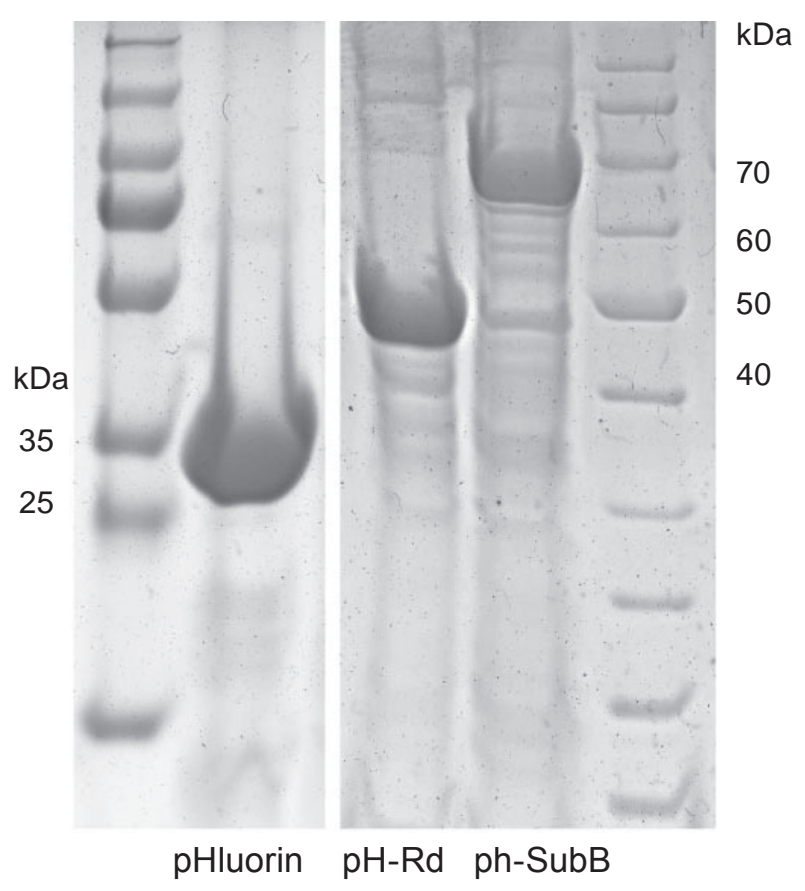

Fig. 2. Electrophoregram of obtained recombinant proteins: pHluorin, $\mathrm{pH}-\mathrm{Rd}$ and $\mathrm{pH}-\mathrm{SubB}$, respectively. The molecular weight indicated near the corresponding bands of molecular weight markers 
sary to verify their properties which could change after their fusion. The verification proceeded in two directions: the establishing of spectral characteristics of obtained proteins and $\mathrm{pH}$-dependent fluorescence as well as determination of functional activity of DT fragments by their ability to interact with the Vero cell line.

The results of spectral investigation of the obtained proteins are presented on Fig. 3, A. Two exci- tation maxima (393 $\mathrm{nm}$ and $480 \mathrm{~nm}$ ) are observed on the obtained excitation spectrum of fluorescent proteins (the emission detected at $510 \mathrm{~nm}$ ), the maximum height of $393 \mathrm{~nm}$ was almost twice as high as $480 \mathrm{~nm}$ peak at $\mathrm{pH}$ 7.2. A single emission maximum of $508 \mathrm{~nm}$, which value was also twice higher under the excitation with wavelength $390 \mathrm{~nm}$ compared with excitation of $480 \mathrm{~nm}$, was obtained on the emission spectra under the excitation of both 390 and

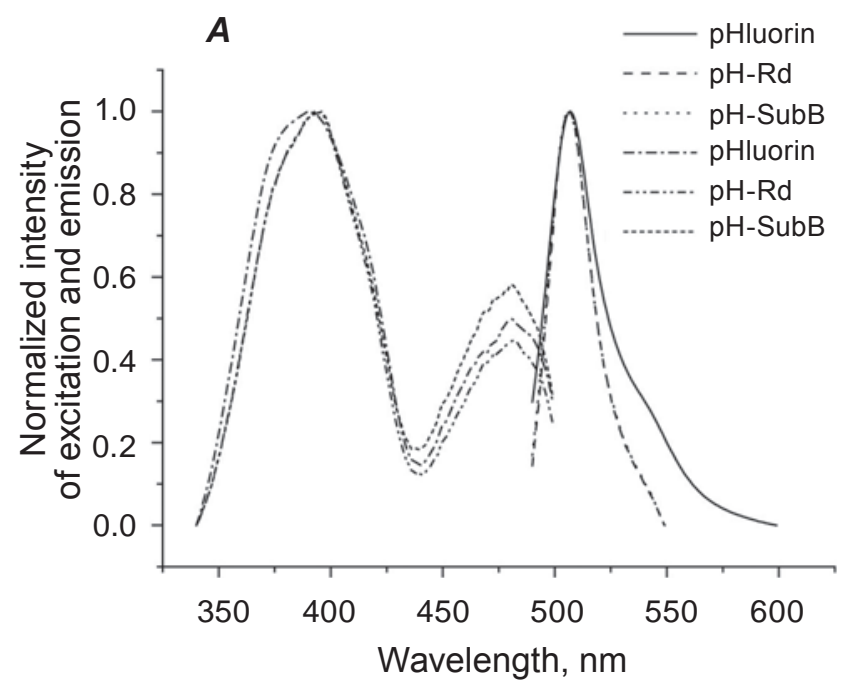

C

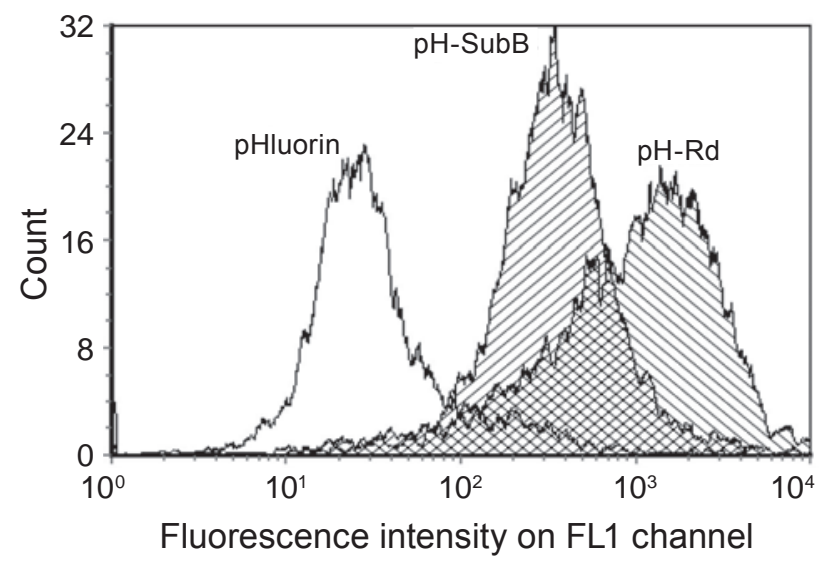

$B$

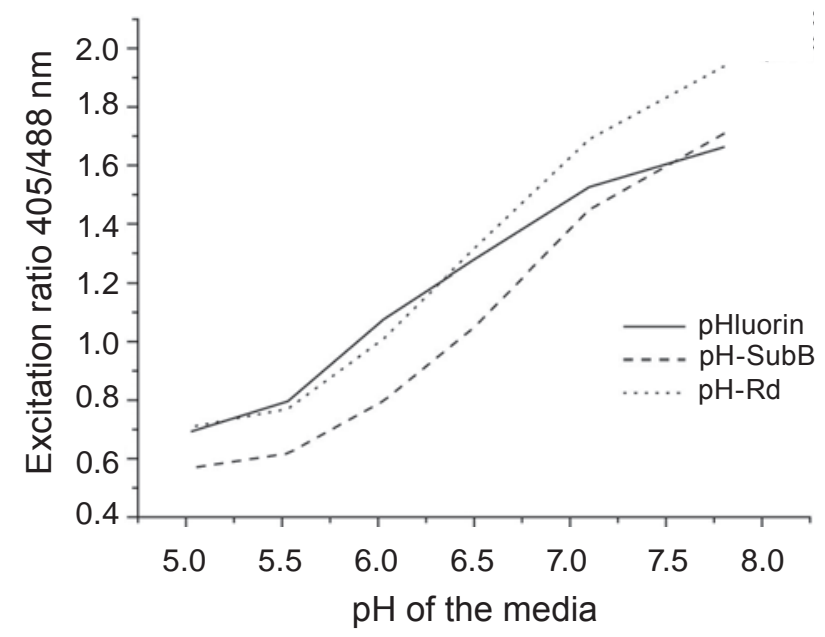

$D$

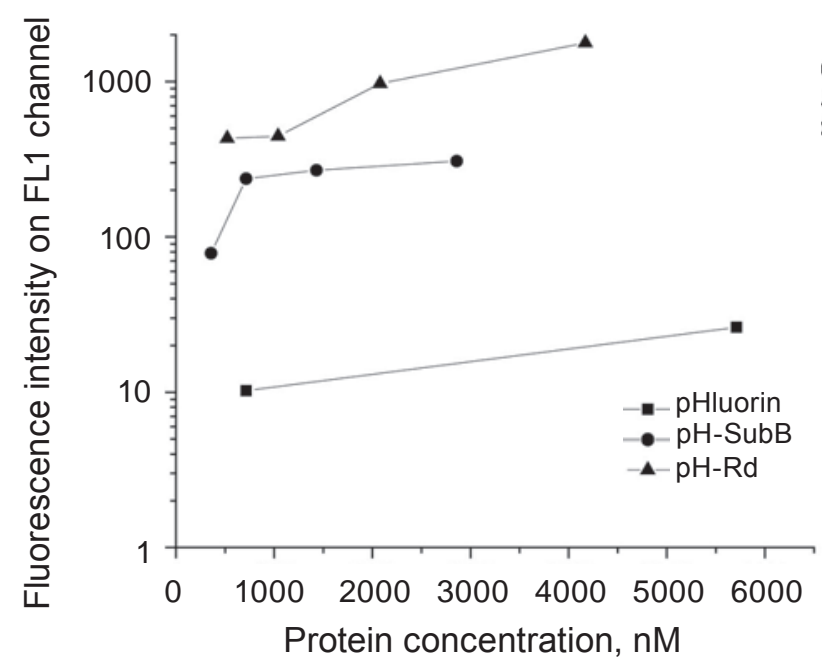

Fig. 3. Functional activity tests of recombinant proteins based on $\mathrm{pH}$-sensitive protein pHluorin: $A$ - the spectral characteristics of obtained proteins. The excitation spectrum recorded with fluorescence detection at $510 \mathrm{~nm}$. The emission spectrum recorded at excitation wavelength $490 \mathrm{~nm}$. B-dependence of excitation ratio $405 \mathrm{~nm} / 488 \mathrm{~nm}$ of obtained proteins on $\mathrm{pH}$ of the medium. Values of this ratio were calculated as the ratio of fluorescence intensity at $510 \mathrm{~nm}$ when excited at $405 \mathrm{~nm}$ to fluorescence intensity at $490 \mathrm{~nm}$ excitation. C- histogram of the flow cytometry of Vero cells stained by $1.4 \mu \mathrm{M}$ pHluorin, $\mathrm{pH}$-Rd and $p H-S u b B$. D-dependence of stained Vero cell fluorescence on concentration of added proteins $p H l u o r i n, p H-R d$ and $p H-S u b B$. Data obtained with flow cytometry 
$480 \mathrm{~nm}$. The shape of the excitation and emission spectra for all the obtained proteins was almost the same. However, the spectra were slightly different in the height of maximum excitation of $480 \mathrm{~nm}$, and an increase of the right arm on the emission spectrum of protein pHluorin compared with the spectra of $\mathrm{pH}-\mathrm{SubB}$ and $\mathrm{pH}-\mathrm{Rd}$. The both peculiarities of the spectra may be connected with different microsurrounding of the fluorescent protein in these structures.

Then it was necessary to check the effect of DT derivatives on $\mathrm{pH}$-sensitive fluorescence of protein pHluorin. The absorption spectra were recorded as pHluorin emission of $510 \mathrm{~nm}$ depending on $\mathrm{pH}$ in MES-gluconate buffer in the $\mathrm{pH}$ range from 7.7 to 5.0. On the obtained spectra one could notice an increase of excitation maximum value of $480 \mathrm{~nm}$ under a decrease of $\mathrm{pH}$ as well as a decrease of excitation maximum value of $390 \mathrm{~nm}$ under a decrease of $\mathrm{pH}$ (data not shown). The plot of the ratio of fluorescence intensities at the wavelength $510 \mathrm{~nm}$ with excitation ratio $405 \mathrm{~nm} / 480 \mathrm{~nm}$ depending on $\mathrm{pH}$ (Fig. 3, B) has shown $\mathrm{S}$-like dependence of this parameter on $\mathrm{pH}$. Plots for proteins $\mathrm{pH}-\mathrm{SubB}$ and $\mathrm{pH}-\mathrm{Rd}$ were of the same shape, but the plot for $\mathrm{pH}-\mathrm{Rd}$ had something higher values than the plot for $\mathrm{pH}-\mathrm{SubB}$. The plot for pHluorin was of more linear shape, than the plots for other proteins. As was mentioned above, these features of $\mathrm{pH}$-dependent fluorescence may be connected with different micro-surrounding of these proteins. Nonetheless, all the obtained proteins demonstrated a strict $\mathrm{pH}$-dependent fluorescence.

The next stage was the examination of ability of the obtained proteins to interact with the Vero line cells, using a flow cytometer. As is seen from Fig. 3, $B$, proteins $\mathrm{pH}-\mathrm{SubB}$ and $\mathrm{pH}-\mathrm{Rd}$ added in concentration of $1.4 \mu \mathrm{M}$ had by 1.5 and 2 orders higher binding to Vero cells compared with protein pHluorin. Results of concentration dependence of binding the obtained proteins to Vero cells are presented in Fig. 3, D. The binding curves of the both DT derivatives fused with pHluorin had a tendency to saturation, while protein pHluorin alone had a weak binding to the cells even in very high concentrations. The highest binding for $\mathrm{pH}-\mathrm{SubB}$ was noted for concentration of about $2.5 \mu \mathrm{M}$, and for protein $\mathrm{pH}-$ $\mathrm{Rd}-$ about $4 \mu \mathrm{M}$. In further investigations we used the above concentrations of proteins. Overall fluorescence intensity of the Vero cells stained with pH-Rd was almost 5 times higher than of cells stained with $\mathrm{pH}-\mathrm{SubB}$. However, since protein pHluorin is ratio- metric, such a peculiarity should not affect further investigations of endosomal $\mathrm{pH}$.

Study of $\mathrm{pH}$ changes inside endosomes loaded with DT fragments. The obtained fluorescent proteins $\mathrm{pH}-\mathrm{SubB}$ and $\mathrm{pH}-\mathrm{Rd}$ were used to investigate $\mathrm{pH}$ inside lysosomes and its change with incubation time. Since $\mathrm{pH}$ gradient inside endosomes after fixation of cells may be abolished, it was necessary to determine the $\mathrm{pH}$ inside the live cells that was done with confocal microscopy with a chamber for live cell imaging.

Since the curves of $\mathrm{pH}$-dependent fluorescence for $\mathrm{pH}-\mathrm{SubB}$ and $\mathrm{pH}-\mathrm{Rd}$ differed, it was necessary to calculate intensity-pH conversion function for each protein. After obtaining images required for calculation of this function the microscope settings in research were not changed. The curves of intensity vs $\mathrm{pH}$ were plotted on the basis of images of PLGA nanoparticles with loaded proteins $\mathrm{pH}-\mathrm{SubB}$ or $\mathrm{pH}-$ $\mathrm{Rd}$ taken at different $\mathrm{pHs}$, and then from this curves intensity-pH conversion function was calculated.

Prior to the beginning of the main experiment the cells were stained with $\mathrm{pH}-\mathrm{SubB}$ or $\mathrm{pH}-\mathrm{Rd}$, the cell images were obtained from the $10^{\text {th }}$ to the $50^{\text {th }}$ min of the experiment. First experiments were also performed with protein pHluorin. They have confirmed that this protein does not interact with cell surface (data not shown).

Thereafter, the obtained images were processed with a special program script and plotted as function of $\mathrm{pH}$ inside endosomes with DT fragments vs incubation time. This plot is presented on Fig. 4. It is seen from the $10^{\text {th }}$ min of research that the primary acidification of the medium occurred in endosomes with DT fragments, that is why they have a lower $\mathrm{pH}$ level relative to buffer solution ( $\mathrm{pH}$ 7.2). But even in a short period of time the endosomes with SubB have a bit higher $\mathrm{pH}$ (about 6.5), while endosomes with $\mathrm{Rd}$ have a lower one (6.3). With time $\mathrm{pH}$ inside endosomes with Rd begin lowering and reaches approximately 5.5 on the $50^{\text {th }}$ min of observation. In contrast to $\mathrm{pH}$ change inside endosomes loaded with $\mathrm{Rd}, \mathrm{pH}$ inside endosomes with SubB remains almost unchanged over the whole time of the observation and achieves about 6.4-6.5.

The presented plot demonstrates that, when Rd absorbed by the cell via endocytosis it undergoes a normal process of endosome maturation via acidification of its medium. However, SubB, namely Tdomain, affected the process of acidification of the endosomal lumen and $\mathrm{pH}$ inside such endosomes 


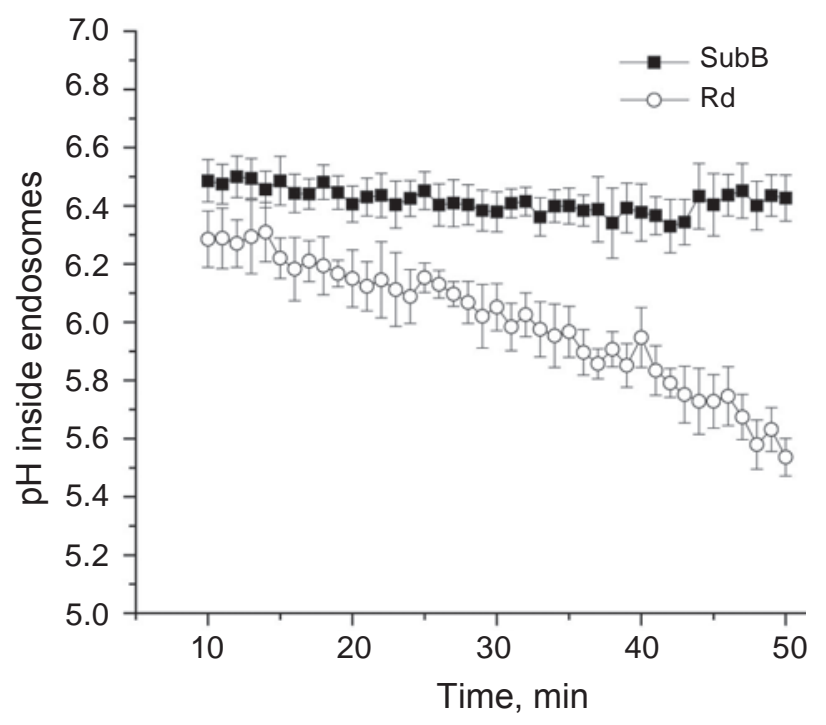

Fig. 4. Time-dependence of $\mathrm{pH}$ inside the endosomes loaded with $\mathrm{pH}-\mathrm{SubB}$ and $\mathrm{pH}-\mathrm{Rd}$ in the cells of the Vero cell line. Results are calculated on confocal microscopy images with the original program script written in Python ( $M \pm S E, n=3)$

also did not change during 50 min of the observation. Thus, after combining the obtained results with those of colocalization with the markers of the endosomal path, we can state that on the $10-50^{\text {th }}$ min of the study SubB was in the compartment of EE, since $\mathrm{pH} 6.5$ corresponds to EE. Rd probably passed through compartments of the EE and LE for the period from the $10^{\text {th }}$ to the $50^{\text {th }} \mathrm{min}$, and maybe some part of this protein arrived to lysosomes that manifested in colocalization with the corresponding endosomal markers and in a decrease of $\mathrm{pH}$ inside endosomes with this protein.

Here we have shown that T-domain affects SubB transport inside the cell and confirmed T-domain ability of regulating endosomal $\mathrm{pH}$ with this protein within. Chenal A. et al. [20] have pointed to a possibility for T-domain of DT to form proton channels in the lipid bilayers of artificial membranes. It is probable that the channel formed by T-domain can compensate the work of vesicular proton pumps that is expressed in maintaining a steady high level of endosomal pH. It is known that most endosomal proteinases activate in the $\mathrm{LE}$ and lysosomes at $\mathrm{pH}$ below 6. Thus, T-domain can inhibit endosome maturation by stabilizing endosomal $\mathrm{pH}$ at the level of 6.5 that will slow-down their transition to LE and activation of endosomal proteases, thus enhancing probability of successful transporting of DT Cd to cytosol.

\section{Acknowledgements}

Plasmid pKK223-3/pHluorin(M153R) was kindly presented by Prof. Tohru Minamino (Precursory Research for Embryonic Science and Technology, Japan Science and Technology Agency, Kawaguchi, Saitama, Japan) and Prof. Gero Miesenböck (Department of Physiology, Anatomy and Genetics, Magdalen College, Oxford, United Kingdom).

Plasmids pGFP-SKD1 $1_{\text {E235O }}$, pCHMP4b-GFP and pCHMP6-GFP were kindly presented by Prof. Maria Jolanta Rędowicz (Department of Biochemistry, Nencki Institute of Experimental Biology, Warszawa, Poland).

The authors are grateful to Prof. Oleksadr Demchenko (Palladin Institute of Biochemistry, Kyiv, Ukraine) for invitation to workshops "Practical course in advanced microscopy" (Zurich, Switzerland, 2013) and "Practical course in advanced biophysical methods" (Pecs, Hungary, 2014) which have given the authors many fruitful ideas in confocal data analysis.

\section{Financial support}

The work was supported by grants for young scientists: Acad R.V. Chagovets (2010) and Acad. M. F. Guly (2011) grants of Palladin Institute of Biochemistry and President of Ukraine grant for young scientists (2013-2014).

\section{ВПЛИВ Т-ДОМЕНУ ДИФТЕРІЙНОГО ТОКСИНУ НА рН ЕНДОСОМ}

\author{
А. Ю. Лабинцев, Н. В. Короткевич, \\ Д. В. Колибо, С. В. Комісаренко
Інститут біохімії ім. О.В. Палладіна
НАН України, Київ;
e-mail: lab.andrey@gmail.com

Ключовим етапом у реалізації цитотоксичної дії дифтерійного токсину (ДТ) є перенесення його каталітичного домену $(\mathrm{Cd})$ 3 ендосом у цитозоль. Головну роль у цьому процесі відіграє транспортний домен (Td), проте молекулярний механізм його функціонування залишається невідомим. Раніше нами було показано, що $\mathrm{Td}$ здатний впливати на ендосомальний транспорт ДТ. Метою цієї роботи було вивчення впливу $\mathrm{Td}$ дифтерійного токсину на компартменталізацію ендосом і на $\mathrm{pH}$ ендосомального середовища. Для цього ми використовували рекомбінантні фрагменти ДТ, 
які відрізнялися лише наявністю $\mathrm{Td}$ в їхньому складі, що були злиті із флуоресцентними протеїнами. Показано, що фрагмент токсину iз $\mathrm{Td}$ повільніше проходив шлях ранні-пізні ендосоми-лізосоми, та мав дещо відмінну від фрагмента ДТ (без Тd) колокалізацію з ендосомальними маркерами. При цьому з 10- до 50-ї хв спостереження рН ендосом, що містять фрагменти ДТ із $\mathrm{Td}$, мали стале значення $\mathrm{pH}(\sim 6,5)$. За цей час для ендосом, що містять фрагменти ДТ без $\mathrm{Td}$, продемонстровано зниження $\mathrm{pH}$ від 6,3 до 5,5. Одержані результати вказують на те, що $\mathrm{Td}$ інгібує закислення ендосомального середовища. Однією з можливих причин цього може бути вплив утвореного Т-доменом іонного каналу на процес зниження $\mathrm{pH}$ ендосом. Ця властивість $\mathrm{Td}$ може не тільки сповільнювати дозрівання ендосом, але і пригнічувати активацію рН-залежних ендосомальних протеїназ, що сприяє успішному транспортуванню $\mathrm{Cd}$ у цитозоль клітини.

Кл ючов і слов а: дифтерійний токсин, Т-домен дифтерійного токсину, ендоцитоз, флуоресцентні протеїни, конфокальна мікроскопія, внутрішньоклітинний транспорт, ендосомальний $\mathrm{pH}$.

\section{ВЛИЯНИЕ Т-ДОМЕНА ДИФТЕРИЙНОГО ТОКСИНА НА рН ЭНДОСОМ}

\section{А. Ю. Лабынцев, Н. В. Короткевич, \\ Д. В. Колибо, С. В. Комисаренко}

\author{
Институт биохимии им. А. В. Палладина \\ НАН Украины, Киев; \\ e-mail: lab.andrey@gmail.com
}

Ключевым этапом в реализации цитотоксического действия дифтерийного токсина (ДТ) является перенос его каталитического домена $(\mathrm{Cd})$ из эндосом в цитозоль. Главную роль в данном процессе играет транспортный домен (Td), однако молекулярный механизм его функционирования остается неизвестным. Ранее нами было показано, что $\mathrm{Td}$ способен влиять на эндосомальный транспорт ДТ. Целью данной работы было изучение влияния $\mathrm{Td}$ дифтерийного токсина на компартментализацию эндосом и на pH эндосомальной среды. Для этого мы использовали рекомбинантные фрагменты ДТ, которые отличались лишь наличием $\mathrm{Td}$ в их составе, и были слиты с флуоресцентыми протеинами.
Показано, что фрагмент токсина с Td медленнее проходил путь ранние-поздние эндосомы-лизосомы, и имел несколько отличную от фрагмента ДТ (без Тd) колокализацию с эндосомальными маркерами. При этом с 10-й по 50-ю мин наблюдения рН эндосом, содержащих фрагменты ДТ с $\mathrm{Td}$, имели постоянное значение $\mathrm{pH} \sim 6,5$, за это время для эндосом, содержащих фрагменты ДТ без $\mathrm{Td}$, продемонстрировано снижение $\mathrm{pH}$ от 6,3 до 5,5. Полученные результаты указывают на то, что Td ингибирует закисление эндосомальной среды. Одной из возможных причин этого может быть влияние образованного Т-доменом ионного канала на процесс снижения $\mathrm{pH}$ эндосом. Это свойство Td может не только замедлять дозревание эндосом, но и ингибировать активацию $\mathrm{pH}$-зависимых эндосомальных протеиназ, что способствует успешной транспортировке $\mathrm{Cd}$ в цитозоль клетки.

Ключевы е слова: дифтерийный токсин, Т-домен дифтерийного токсина, эндоцитоз, флуоресцентные протеины, конфокальная микроскопия, эндосомальный $\mathrm{pH}$.

\section{References}

1. Kolibo D. V., Labyntsev A. J., Romaniuk S. I., Kaberniuk A. A., Oliinyk E. S., Korotkevich N. V., Komisarenko S. V. Immunobiology of diphtheria. Recent approaches for the prevention, diagnosis, and treatment of the disease. Biotechnol. Acta. 2013;6(4):43-62.

2. Huotari J., Helenius A. Endosome maturation. EMBO J. 2011;30(17):3481-3500.

3. Schmidt O., Teis D. The ESCRT machinery. Curr. Biol. 2012;22(4):R116-R120.

4. Fujita H., Yamanaka M., Imamura K., Tanaka Y., Nara A., Yoshimori T., Yokota S., Himeno M. A dominant negative form of the AAA ATPase SKD1/VPS4 impairs membrane trafficking out of endosomal/lysosomal compartments: class E vps phenotype in mammalian cells. J. Cell Sci. 2003;116(2):401-414.

5. Guha S., Padh H. Cathepsins: fundamental effectors of endolysosomal proteolysis. Indian $J$. Biochem. Biophys. 2008;45(2):75-90.

6. Labyntsev A. J., Kolybo D. V., Yurchenko E. S., Kaberniuk A. A., Korotkevych N. V., Komisarenko S. V. Effect of the T-domain on intracellular transport of diphtheria toxin. $U k r$. Biochem. J. 2014;86(3):77-87. 
7. Morimoto Y. V., Kojima S., Namba K., Minamino T. M153R Mutation in a pH-Sensitive Green Fluorescent Protein Stabilizes Its Fusion Proteins. PLoS ONE. 2011;6(5):e19598.

8. Miesenböck G., De Angelis D. A., Rothman J. E. Visualizing secretion and synaptic transmission with $\mathrm{pH}$-sensitive green fluorescent proteins. Nature 1998;394(6689):192-195.

9. Labyntsev A. J., Korotkevych N. V., Manoilov K. J., Kaberniuk A. A., Kolybo D. V., Komisarenko S. V. Recombinant fluorescent models for studying the diphtheria toxin. Russ. J. Bioorganic Chem. 2014;40(4):401-409.

10. Schägger $H$., von Jagow G. Tricinesodium dodecyl sulfate-polyacrylamide gel electrophoresis for the separation of proteins in the range from 1 to $100 \mathrm{kDa}$. Anal. Biochem. 1987;166(2):368-379.

11. Schindelin J., Arganda-Carreras I., Frise E., Kaynig V., Longair M., Pietzsch T., Preibisch S., Rueden C., Saalfeld S., Schmid B., Tinevez J. Y., White D. J., Hartenstein V., Eliceiri K., Tomancak P., Cardona A. Fiji: an open-source platform for biological-image analysis. Nat. Methods. 2012;9(7):676-682.

12. Bolte S., Cordelières F. P. A guided tour into subcellular colocalization analysis in light microscopy. J. Microsc. 2006;224(3):213-232.

13. Chudina T., Labyntsev A., Manoilov K., Kolybo D., Komisarenko S. Cellobiose-coated poly(lactide-co-glycolide) particles loaded with diphtheria toxoid for per os immunization. Croat. Med. J. 2015;56(2):85-93.
14. Van Rossum G., de Boer J. Interactively testing remote servers using the python programming language. CWI Quarterly. 1991;4(4):283-303.

15. Bradski G. OpenCV. Dr Dobbs J. Softw. Tools. 2000.

16. Hunter J. D. Matplotlib: A 2D graphics environment. Comput. Sci. Eng. 2007;9(3):90-95.

17. Walt S. van der, Colbert S. C., Varoquaux G. The NumPy array: a structure for efficient numerical computation. Comput. Sci. Eng. 2011;13(2):22-30.

18. Katoh K., Shibata H., Suzuki H., Nara A., Ishidoh K., Kominami E., Yoshimori T., Maki M. The ALG-2-interacting Protein Alix Associates with CHMP4b, a Human Homologue of Yeast Snf7 That Is Involved in Multivesicular Body Sorting. J. Biol. Chem. 2003;278(40):3910439113.

19. Yorikawa C., Shibata H., Waguri S., Hatta K., Horii M., Katoh K., Kobayashi T., Uchiyama Y., Maki M. Human CHMP6, a myristoylated ESCRT-III protein, interacts directly with an ESCRT-II component EAP20 and regulates endosomal cargo sorting. Biochem. $J$. 2005;387(1):17-26.

20. Chenal A., Prongidi-Fix L., Perier A., Aisenbrey C., Vernier G., Lambotte S., Fragneto G., Bechinger B., Gillet D., Forge V., Ferrand M. Deciphering membrane insertion of the diphtheria toxin $\mathrm{T}$ domain by specular neutron reflectometry and solid-state NMR spectroscopy. J. Mol. Biol. 2009;391(5):872-883.

Received 23.06.2015 